\title{
空撮画像を用いた地震による被害建物の抽出
}

\section{Automated Detection of Damaged Buildings due to Earthquakes using Aerial HDTV and Photographs}

\author{
青木 久*・松岡 昌志** ・ 山崎 文雄** \\ Hisashi AOKI, Masashi MATSUOKA and Fumio YAMAZAKI
}

\begin{abstract}
We studied the possible use of aerial high-definition television (HDTV) images taken after the 1995 Kobe earthquake, to establish a methodology for an automated detection of building damage. The relationship between the degree of building damage and the color and edge indices from the aerial images were examined by image processing techniques. The characteristics of building damage were defined on the basis of hue, saturation, brightness and edge intensity. Using a threshold value of these parameters, the study areas were classified into damaged and undamaged pixels. A filter analysis was further conducted to these pixels and damaged buildings were identified. The estimated damage distribution by the proposed methodology agrees well with the field survey data and the visual inspection of the aerial HDTV and photographs.
\end{abstract}

Keywords : Aerial Images, Image Processing, Automated Detection, Building Damage, The 1995 Kobe Earthquake

\section{1.はじめに}

地震直後における早期被害把握は，緊急対応や応急 復旧計画の立案のために極めて重要である。広域な被 害状況の把握手法として，宇宙や上空からのリモート センシング技術の利用が考えられる。この中で，軽飛 行機からの航空写真やへリコプターからの空撮テレビ ジョン映像などは，即時性にとくに優れていることか ら報道活動や警察・消防等の情報収集に利用されてき た。1995年兵庫県南部地震や1999年台湾集集地震にお いても，被害状況の空からの撮影が盛んに行われ，報 道等に広く利用された。へリコプターからのビデオカ メラやスチルカメラによる被害情報収集に関する研究 は以前にも行われている。旧建設省は総合技術開発プ

* 基礎地盤コンサルタンツ株式会社（元 理化学研究所）

Kiso-Jiban Consultants Co., Ltd.

**理化学研究所地震防災フロンティア研究センター

(現 防災科学技術研究所)

Earthquake Disaster Mitigation Research Center

干673-0433 兵庫県三木市福井三木山2465-1

2465-1 Mikiyama, Miki, Hyogo 673-0433, Japan.

「写真測量とリモートセンシング」VOL. 40, NO. 4, 2001
ロジェクトとして，道路や河川の地震被害をへリコプ ターからのビデオ映像などから判読する一連の研究1) を行い，橋脚や盛土の模擬被害の撮影実験なども行っ ている。しかし，実映像・画像を用いた建物被害の定 量的な把握は行われていない。

これまでに筆者らは，赀撮ハイビジョン映像を利用 した目視による建物被害判読の可能性や，画像解析に よる被害抽出について基礎的検討を行ってきた ${ }^{2)-4)}$ 。 変化地域は，例えば，人工衛星画像の場合には地震前 後の画像の違いから抽出可能である5)。しかし，ヘリコ プタ一等による空撮映像では同じ軌道から撮影した被 害前の映像があるとは限らないことから，地震後のみ の映像を利用することが現実的である。本論はこれま で報告を行ってきた空撮映像による建物被害の抽出手 法に修正を加えて発展させた。また，この手法を航空 写真にも適用し, 被害建物の抽出精度と確認可能な建 物被害レベルを明らかにした。

\section{2. 空撮画像}

\section{1 ハイビジョン空撮映像}

本検討で使用する空撮映像は NHK が兵庫県南部 


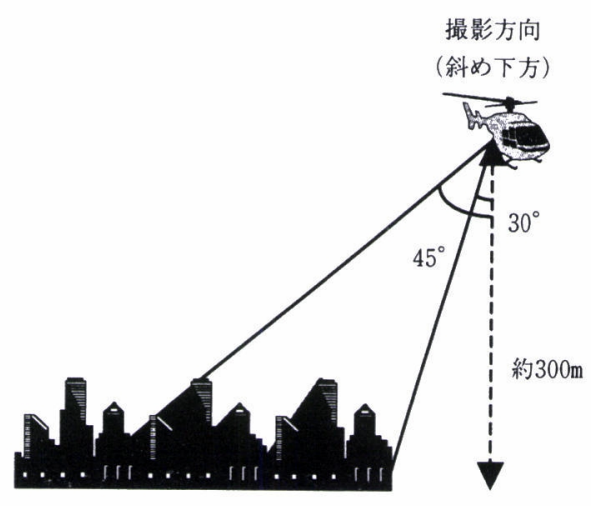

図 1 空撮映像の撮影方法

地震の発生直後から, 高度 $300 \mathrm{~m}$, 撮影角度 $30 \sim 45$ 度 (鉛 直方向を基準）を保持しつつ(図 1 参照)，被災地全域 を撮影した膨大な記録の一部である。本映像はへリコ プター搭載ハイビジョン空撮システムにより撮影され たもので, NTSC 方式の従来映像と比較して高画質で 詳細な情報といえる。また，本映像はサイドルッキン グ画像であることから，建物上部の情報に加之建物側 面の情報が得られている。しかし，画面手前に位置す る建物の背後が死角となる場合もある。ここでは，空 撮映像の 1 コマをビットマップ形式の画像ファイル (1920×1035画素)に変換して使用した。対象地域は兵 庫県西宮市内の $200 \mathrm{~m} \times 230 \mathrm{~m}$ ，約 $46,000 \mathrm{~m}^{2}$ の範囲であ り，目視被害判読を行った2),3)地域の一部である(図 2 参照）。画像の地上分解能は画像下部で約 $9 \mathrm{~cm}$, 画面上 部で約 $17 \mathrm{~cm}$ である。撮影日は地震の10日後 (1995年 1 月27日）であり，一部の被害建物にはブルーシートに よる防水対策が施されていた。

\section{2 画像処理とトレーニングデータの選定}

被害抽出は木造建物を対象とした。多くの倒壊建物 は落下した瓦と葺土の茶褐色が混在し，無被害建物は 建物の輪郭部が明瞭であり形状の確認が可能なこと が, 両者を区別する要因と考えられ，この特徵が複数 の判読員の被害判読を容易にさせた2)。そこで, 建物被 害および無被害とみなされる範囲をトレーニングデー タとして選定し, 選定された画像に扔ける色情報と輪 郭情報（エッジ情報）から両者の判別の可能性につい て検討した。選定したトレーニングデータは表 1 に示 すとおりで，被害建物として倒壊建物 (C) と全壊建物 （D）に，無被害として無被害建物 $(\mathrm{Nb})$ と無被害領域 $(\mathrm{Nz})$ とに分け，それぞれについて 5 地域を選定した。

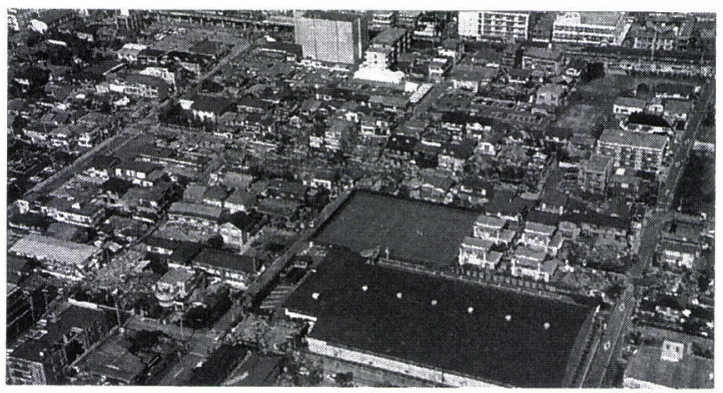

図2 本研究で対象にした空撮画像

なお, 被害建物と無被害建物は地上調查データ ${ }^{61,7)}$ お び画像の目視判読結果 ${ }^{2}$ に基づき選定した。

トレーニングデータの色情報と輪郭情報の検討に先 立ち, 空撮画像全域に対して前処理を行った。まず， 線形変換法 ${ }^{8}$ による濃度変換を行った。ここでは, $\mathrm{R}$, $\mathrm{G}, \mathrm{B}$ の各チャンネルに対して, 原画像の約 $98 \%$ が変換 後の濃度值の 0 から 255 の範囲に含まれるように変換 した。また，建物の影などを含む太陽光の影響を，比 演算処理9 を応用したRGB 值の色補正により低減し た。その際, 基準となるバンドをモノクロ画像の強度 にあたる明度 (I)として， R， G，B それぞれの值を明 度で除した（基準化した）。

\section{3．被害地域における色情報の特徵}

テレビジョン映像で映し出される表色系 RGB は, 一般に独立な成分でなく互いに強い相関がある。一方, 顕色系で使われる HSI では，色を定量的に表現するた めに, 色の性質を独立した 3 要素で規定している8)。各 要素は，色の種類を表す色相 (Hue)，色の濃さを表す 彩度 (Saturation), 色の明るさを表す明度 (Intensity) である。これらのことから, HSI は判別要素として $\mathrm{RGB}$ よりも適切な色情報と考えられる。色相 $(\mathrm{H})$, 彩 度（S）は基準化した $\mathrm{R}, \mathrm{G}, \mathrm{B}$ から算出し, 最小值か ら最大値を 0 から $255 に$ 線形に割り当てて画像化した。 また明度（I）は比演算処理の際に求めた值を画像化し た。この $\mathrm{H}, \mathrm{S}$ ，I值を以降の解析に用いる。

表 1 に示すトレーニングデータについて, 各 $\mathrm{H}, \mathrm{S}$, Iの画素値およびウィンドウ内より算出される平均 值，中間值，分散の 3 つの特徵量について検討した。 ウインドウのサイズは画像上部に位置する建物と解像 度を考慮し， $7 \times 7($ 約 $120 \times 120 \mathrm{~cm})$ ウインドウとし， 各特徵量はトレーニングデータごとに頻度の総和が 1 
表 1 トレーニングデータの特徵と判別結果（白色：被害画素, 灰色：無被害画素）

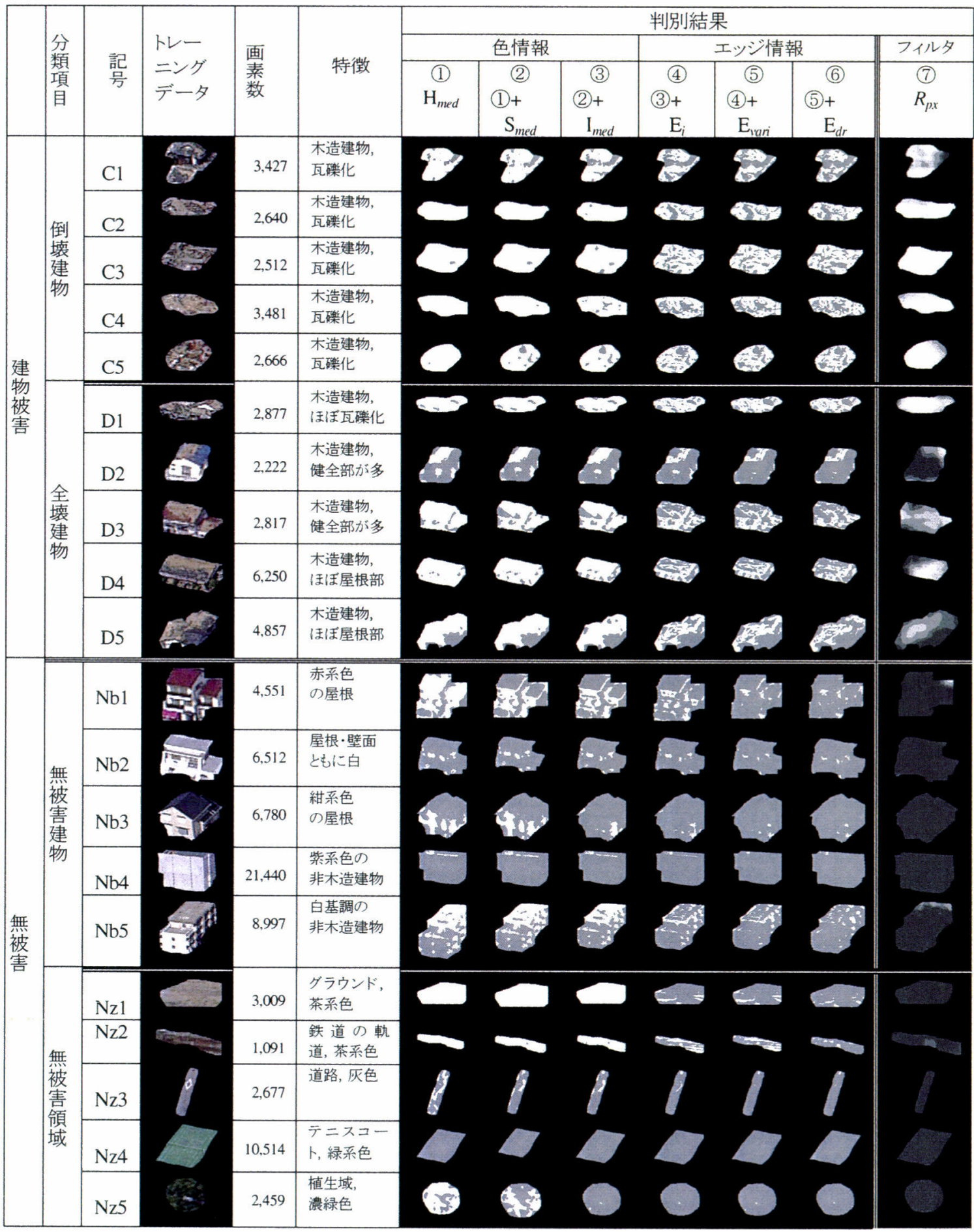




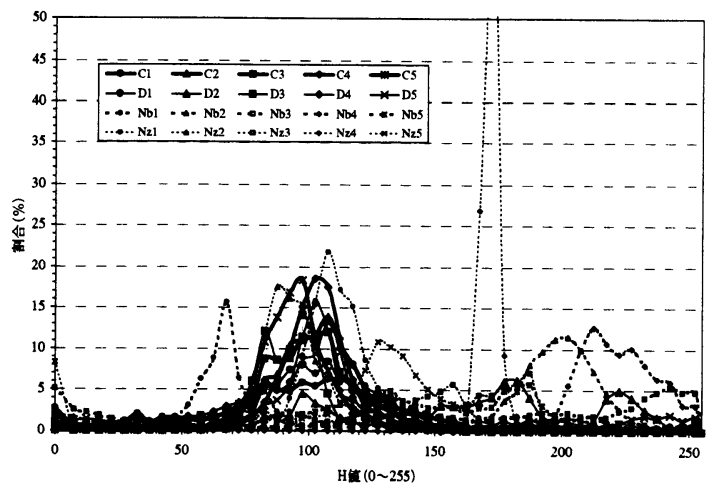

(a) 画素値

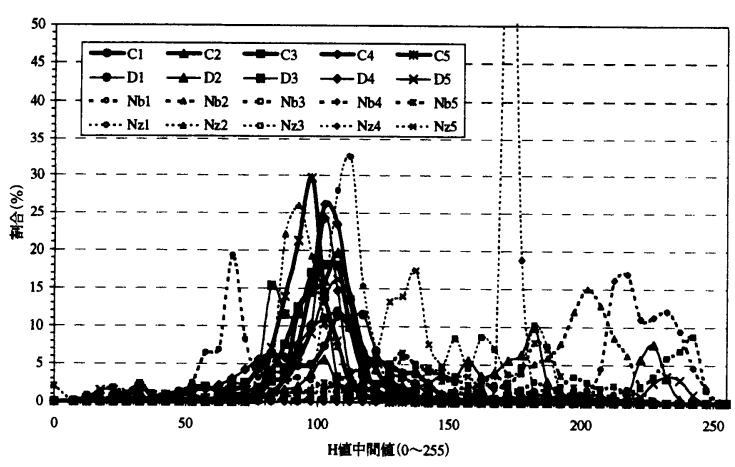

(c) 中間値

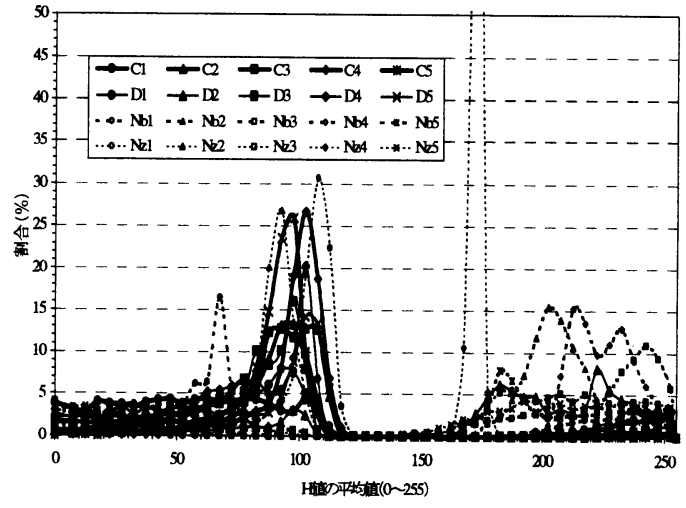

(b) 平均値

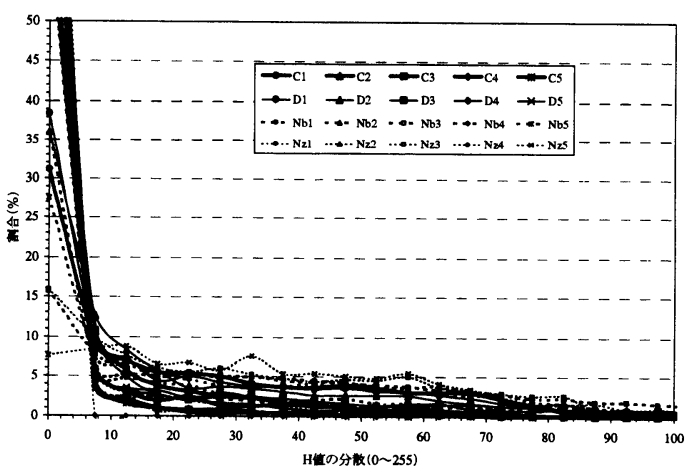

(d) 分散

図 $3 \mathrm{H}$ 值における画素值および $7 \times 7$ 画素における特徵量のトレーニングデータごとの相対頻度分布

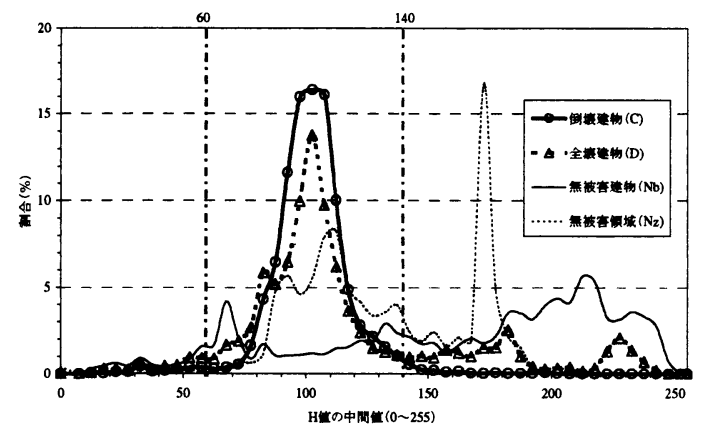

図 $4 \mathrm{H}$ 值の中間値 $\left(\mathbf{H}_{m e d}\right)$ における平均相対頻度分布

になるように正規化している。四 3 には H 值における それぞれの值の正規化頻度分布（相対頻度分布）を卜 レーニングデータごとに線種を変えて示す。困 $3(\mathrm{a})$ (c)に示す画素值，平均值，中間値の相対頻度分布では 建物被害 $(\mathrm{C}, \mathrm{D})$, 無被害建物 $(\mathrm{Nb})$, 無被害領域 $(\mathrm{Nz})$ 間でそれぞれ分布が異なり，その違いは中間値におい て顕著である。図 3 (d)に示す分散からはトレーニング データごとの分布に明確な違いはみられない。 $\mathrm{H}$ 值の $-30-$

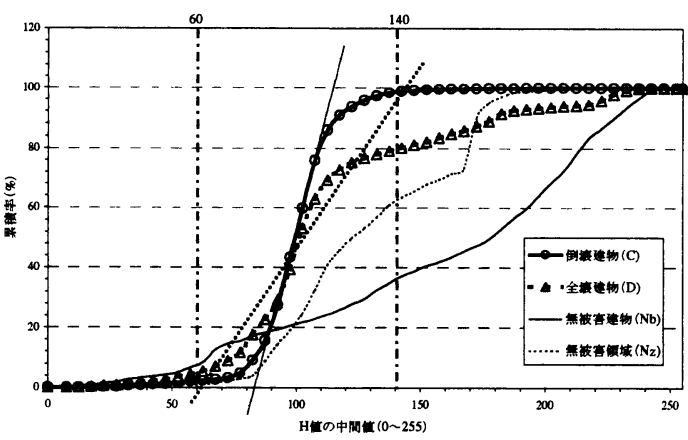

図 $5 \mathrm{H}$ 値の中間值 $\left(\mathbf{H}_{m e d}\right)$ における平均相対頻度の累積分 布

中間值 $\left(\mathrm{H}_{\text {med }}\right)$ について, 分類項目ごとの相対頻度の 平均值（ここでは, 平均相対頻度と呼ぶ）を図 4 に示 す。これより, 倒壊建物 (C) や全壊建物 (D) はピー クが100 (約140度) 付近にあることがわかる。この領 域は橙〜黄色を示しており, 莫土とみなされる代表的 な茶褐色と一致する。四 5 には分類項目ごとの平均相 対頻度の累積分布を示す。倒壊建物 $(\mathrm{C})$ と全壊建物 (D) の累積率の傾きは無被害建物 $(\mathrm{Nb})$ および無被害領域 


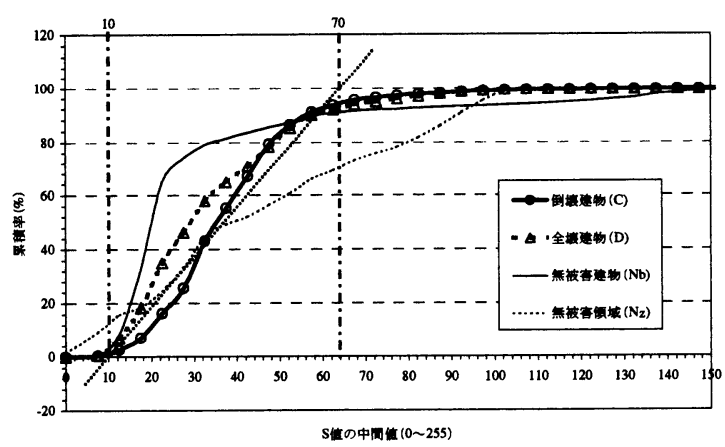

目 $6 \mathrm{~S}$ 值の中間值 $\left(\mathbf{S}_{m e d}\right)$ における平均相対頻度の累積分 布

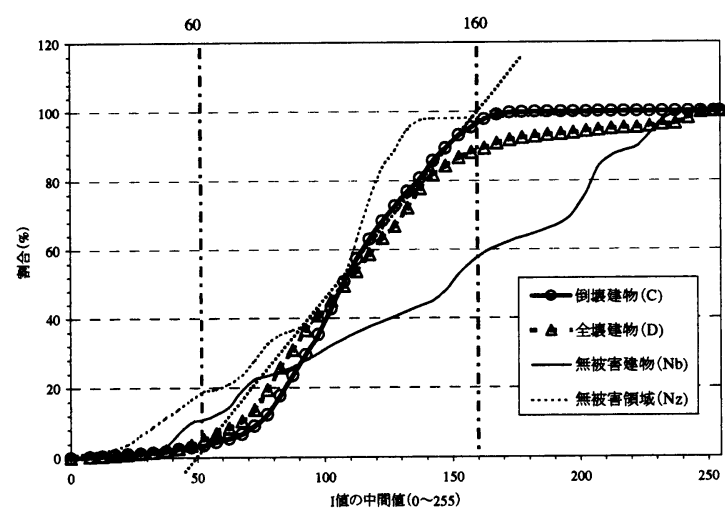

図 7 | 值の中間值（I $\left.\mathbf{I}_{m e d}\right)$ における平均相対頻度の累積分 布

$(\mathrm{Nz})$ のそれとは大きく異なる。同様に，S および I の 画素值抒よび平均值，中間值，分散について相対頻度 分布およびその累積分布の特徵を検討した。図 6,7 には S, I 值の中間值 $\left(\mathrm{S}_{\text {med }}, \mathrm{I}_{\text {med }}\right)$ における平均相対 頻度の累積分布を分類項目ごとに示す。四 6 に示す $\mathrm{S}$ 值の中間値では無被害領域 $(\mathrm{Nz})$ の傾きが他の分類項 目とは異なり,一方, 図 7 の I 值の中間值からは無被害 建物（Nb）が他とは異なった傾きを示す。

以上までの検討から，表 2 に各特徵量の建物被害 (C，D）と無被害（Nb，Nz) を区別する指標としての 有効性の評価をまとめて示す。 $\mathrm{H}, \mathrm{S}, \mathrm{I}$ の中間値 $\left(\mathrm{H}_{m e d}\right.$, $\mathrm{S}_{\text {med }}, \mathrm{I}_{\text {med }}$ )が，両者を判別する特徵量として適当であ ることが判明した。そこで，これらの特徴量について 判別のための閾值を考える。ここでは累積分布の傾き を参考にし，全壊建物 (D) の累積分布の傾きを近似す る線（図 5 ～７中の点線）が累積率 $0 \%$ と 100\%となる 範囲に該当する画素を被害とした。その範囲は $\mathrm{H}_{\text {med }}$

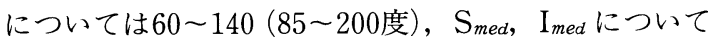
はそれぞれ10７0，60～160となる。つまり，図 5〜7
表 2 建物被害の判別指標評価（色情報）

(O)：非常に有効 $\bigcirc$ : 有効 $\triangle$ : やや有効 $\times$ : 無効

\begin{tabular}{|c|c|c|c|c|c|}
\hline & & \multicolumn{4}{|c|}{ 判別指標 } \\
\hline & & 画素值 & 平均值 & 中間值 & 分 散 \\
\hline \multirow{3}{*}{$\begin{array}{c}\text { 色 } \\
\text { 情 } \\
\text { 報 }\end{array}$} & H 值 $($ 色相 $)$ & $\triangle$ & $\bigcirc$ & $\bigcirc$ & $\times$ \\
\cline { 2 - 6 } & $\mathrm{S}$ 值 $($ 彩度 $)$ & $\triangle$ & $\triangle$ & $\bigcirc$ & $\times$ \\
\hline
\end{tabular}

中の点線よりも傾きが小さいものは無被害として判別 される。トレーニングデータに対して，上記の閾值を 適用し判別した分類結果を表 $1 の$ (1) (3)に示寸。建物 被害として判別された画素を白色，無被害と判別され た画素を灰色としている。(1)に示す $\mathrm{H}_{\text {med }}$ により建物 被害 $(\mathrm{C}, \mathrm{D})$ と無被害 $(\mathrm{Nb}, \mathrm{Nz})$ が概ね判別される。 しかし，Nb1(赤系色の屋根) が被害地域と誤判別され るなど，判別の精度としては十分ではない。これに， $\mathrm{S}_{m e d}$ の閾值を組み合わせた結果 (2) からは，Nb1（赤 系色の屋根)が無被害として判別されている。そして, (3)に示す $\mathrm{I}_{m e d}$ を組み合わせた結果からは，Nb3（明る い壁）および Nz5（植生）が無被害として正しく判別 されるようになる。以上より，色情報である $\mathrm{H}_{m e d}$, $\mathrm{S}_{\text {med }}, \mathrm{I}_{\text {med }}$ は建物被害と無被害を判別する指標として 概ね有効であることがわかったが，表 1 の(3に示すよ うに，これら 3 指標を用いても Nb5（非木造建物の屋 上部）や建物輪郭部，Nz1（グラウンド）や Nz2（鉄 道の軌道）が被害として誤判別される。

\section{4. 無被害地域におけるエッジ情報の特徵}

無被害にもかかわらず被害と誤判別された画素と実 際の被害画素との違いについて考察すると，グラウン ド（Nz1）や非木造建物（Nb5）の屋上部は，建物被害 $(\mathrm{C}, \mathrm{D})$ と比較して濃度変化がみられない。一方，鉄道 の軌道 $(\mathrm{Nz} 2)$ や建物輪郭部は急激な濃度変化とその連 続した線要素がみられる。つまり，誤判別の要因とし て濃度変化が極端に少ない領域（非エッジ領域）ある いは濃度変化が極端に大きい領域 (明確なエッジ領域) およびその線要素（エッジ方向）が考えられる。そこ で，建物被害と誤判別される無被害地域の判別精度を 高めることを目的に，トレーニングデー夕における エッジ情報の特徵を検討する。エッジとは画像を特徵 づける線や輪郭の要素であり, 近接画素における濃度 変化を意味する。エッジ強度とエッジ方向はテンプ 

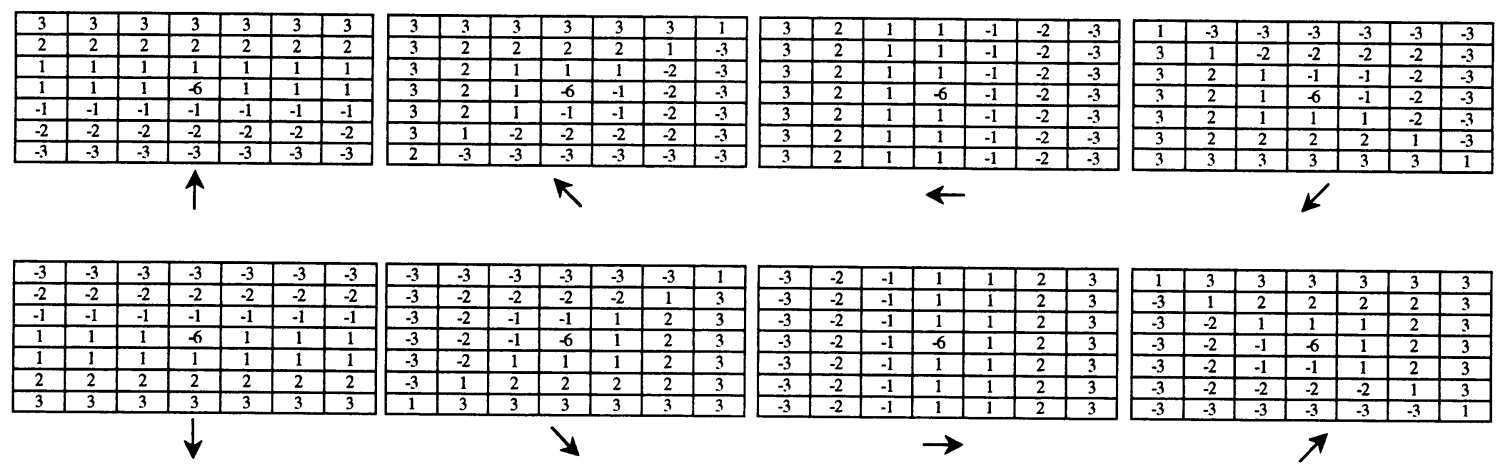

図 $87 \times 7$ テンプレート型エッジ検出オペレータ

レート型のエッジ検出オペレータ等息から抽出でき る。ここでは, エッジ強度は局所積和演算から求まる 微分值とし, エッジ方向の算出には 8 方向 $(0,45$, $90,135,180,225,270,315$ 度)のエッジに反応する 8 個のテンプレートから構成される $3 \times 3$ の Prewitt のテンプレート型エッジ検出オペレータ8)を用いた。 また，テレビカメラなどで撮影された画像は一般的に 鮮鋭度が低いため, 隣り合う画素の濃度值が急激に変 化せず, $\pm 2,3$ 画素の範囲で濃淡が徐々に変化してい ると考えられる。そこで, 上記の $3 \times 3$ テンプレート を $5 \times 5,7 \times 7$ に拡張したテンプレートを作成した。 それぞれ， $5 \times 5,7 \times 7$ テンプレート型エッジ検出 オペレータとした。困 8 には $7 \times 7$ テンプレート型 エッジ検出オペレータの例を示す。エッジ強度は 8 方 向のオペレー夕すべてに対して計算される最も大きい 值を, エッジ方向はその最大值をとるオペレータの方 向とする。

3つのテンプレートを用いて，トレーニングデータ ごとのエッジ強度 $\left(\mathrm{E}_{i}\right)$ の相対頻度分布およびその累 積分布を求め, 無被害地域(無被害建物と無被害領域) の抽出可能性を検討した。例として図 9 に, $7 \times 7$ テ ンプレートにおける $\mathrm{E}_{i}$ 值の相対頻度の累積分布を示 す。また，テンプレート内における $\mathrm{E}_{i}$ の分散 $\left(\mathrm{E}_{\text {vari }}\right)$ の累積分布を図10に示す。ただし，被害建物 (C, D) においては，それぞれの相对頻度の平均值である。点 線で示す無被害領域の累積分布の傾きは被害建物の傾 きと比べて大きく，一方，細実線で示す無被害建物は 傾きが小さい。これは無被害領域ではエッジ強度が小 さく，無被害建物にはエッジ強度が小さい画素から大 きい画素までが一様に存在することを意味する。その 傾向は $7 \times 7$ テンプレートの場合が最も顕著であり， $5 \times 5$ テンプレート, Prewitt テンプレートとウイン

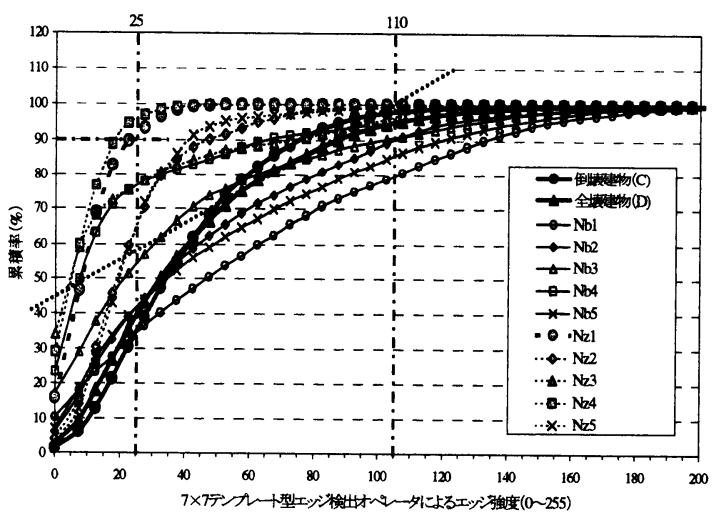

図 $97 \times 7$ テンプレート型エッジ検出オペレータによる エッジ強度 $\left(\mathbf{E}_{i}\right)$ の相対頻度の累積分布

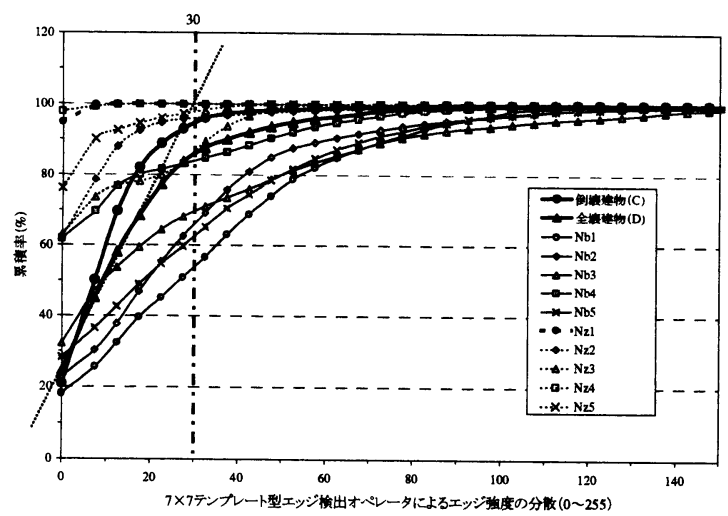

図10 $7 \times 7$ テンプレート型エッジ検出オペレータによる エッジ強度の分散 $\left(\mathbf{E}_{\text {vari }}\right)$ における相対頻度の累積分 布

ドウサイズが小さくなるに従って明瞭でなくなる。表 3 にはテンプレートごとの無被害地域抽出の有効性を まとめて示す。つまり， $7 \times 7$ テンプレートから算出 される $\mathrm{E}_{i}$ 抢よび $\mathrm{E}_{\text {vari }}$ の範囲を限定することで, 被害 建物と無被害地域を概ね分離できそうである。その範 
囲は Nz1 (グラウンド) の画素が $90 \%$ 以上含まれる $\mathrm{E}_{i}$ を被害建物の下限值, 全壊建物 (D) の傾きの近似線が 累積率100\%となる值を上限值と考之，それぞれの值は 25，110をとる。また， Evari からは，全壊建物 (D) の 傾きの近似線が累積率100\%となる值（30）から大きい 画素を無被害建物として抽出できそうである。

色情報に基づく判別結果に, 被害建物の $\mathrm{E}_{i}$ の下限, 上限值を適用した判別結果を表 1 の(4)に示す。これに より, Nb5 (非木造建物の屋上部), Nz1 (グラウンド) や Nz2（鉄道の軌道）の多くの画素を無被害と判別す ることができる。この処理により CやDの被害建物に ついても無被害と判別される画素がみられるが, 後述 するフィル夕解析によりその誤判読の影響を低減する ので，それほど問題とはならない。 $\mathrm{E}_{\text {vari }}$ の閾值を適用 した結果を表 1 の(5)に示す。Nb1～Nb5の無被害建物 の輪郭部において誤判別画素の減少がみられるもの の，依然，Nz2 (鉄道の軌道)の画像の一部は被害画素 と誤判読される。これは，以上までの処理では，鉄道 や道路のように 1 方向に連続したエッジを無被害とし てみなせないからである。そこで, エッジ強度が求ま るテンプレートの方向をエッジ方向とし，画素ごとに 得られるエッジ方向に対してさらに移動ウインドウを 施して，そのウインドウ内に打けるエッジ方向の頻度 を計算した。ウインドウのサイズは $7 \times 7$ として，ウ インドウ内の49画素について，エッジ方向を持つ画素 の占める割合を 8 方向ごとに計算し，その最大值を最 頻度とした。そして, 最頻度 $\left(\mathrm{E}_{d r}\right)$ を0 255に割り 当てた。図11にトレーニングデータにおける $E_{d r}$ の相 対頻度の累積分布を示す。Nz2(鉄道の軌道) が他とは 異なる特徵を示し, 128を境に傾きが異なる。 $\mathrm{E}_{d r}$ が128 以上の画素が鉄道の軌道を含む画像に多くみられるこ

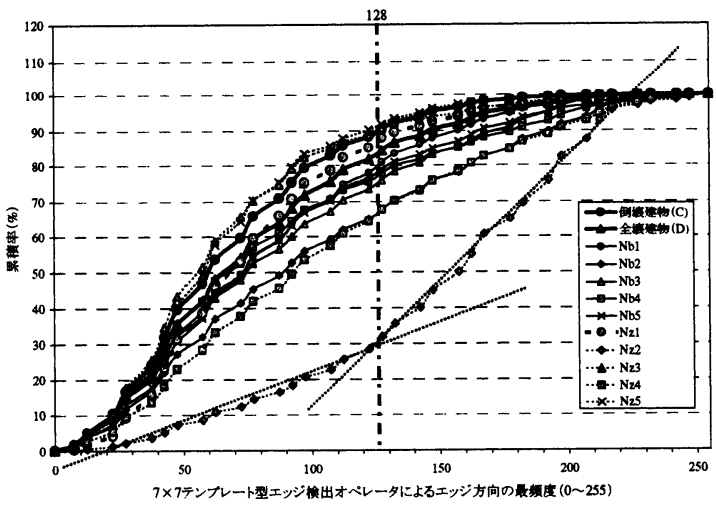

図11 $7 \times 7$ テンプレート型エッジ検出オペレータによる エッジ方向の最頻度 $\left(\mathbf{E}_{d r}\right)$ における相対頻度の累積 分布

とからっこの值より大きい画素を無被害と判断できる。 表 1 の6)には前述までの処理に $\mathrm{E}_{d r}$ の閾値による判 別を加えた結果を示す。これにより，Nz2にみられた誤 判別画素をより低減できる。

\section{5. 被害建物の自動判読}

前述までの手順により, 色相 $(\mathrm{H})$, 彩度 $(\mathrm{S})$, 明度 (I) の各中間值 (それぞれ $\mathrm{H}_{\text {med }}, \mathrm{S}_{\text {med }}, \mathrm{I}_{\text {med }}$ )，エッジ 強度 $\left(\mathrm{E}_{i}\right)$ ，エッジ強度の分散 $\left(\mathrm{E}_{\text {vari }}\right)$ および，エッジ 方向の最頻度 $\left(\mathrm{E}_{d r}\right)$ の 6 指標を用いて, 表 4 に示寸閾 值を用いることで被害画素が抽出できることを示し た。ここでは，画素レベルで抽出した建物被害に対し て，フィル夕解析による空間情報の変換処理8)を行い, 建物 1 棟レベルで表現することを試みる。大きな被害 を受けている建物ほど被害画素の密度が高いことか ら, フィル夕解析の特徵量として, 図12に示す局所領 域における抽出画素の割合 $\left(R_{p x}\right)$ を求めた。局所領域

表 3 建物被害の判別指標評価（エッジ情報）

( ) : 非常に有効 $\bigcirc$ : 有効 $\triangle$ : やや有効 $\times$ : 無効

\begin{tabular}{|c|c|c|c|c|}
\hline & & \multicolumn{3}{|c|}{ 判別指標 } \\
\hline & & エッジ強度 & エッジ強度の分散 & エッジ方向の最頻度 \\
\hline \multirow{4}{*}{ エッジ情報 } & Prewitt & $\triangle$ & $\triangle$ & $\triangle$ \\
\cline { 2 - 5 } & $5 \times 5$ テンプレート & $\bigcirc$ & $\bigcirc$ & $\bigcirc$ \\
\cline { 2 - 5 } & $7 \times 7$ テンプレート & $\bigcirc$ & $\bigcirc$ & $\bigcirc$ \\
\hline
\end{tabular}

表 4 被害画素を判別するための閾値

\begin{tabular}{|c|c|c|c|c|c|c|}
\hline 判別指標 & $\mathrm{H}_{\text {med }}$ & $\mathrm{S}_{\text {med }}$ & $\mathrm{I}_{\text {med }}$ & $\mathrm{E}_{i}$ & $\mathrm{E}_{\text {vari }}$ & $\mathrm{E}_{d r}$ \\
\hline 閾值 & $60 \sim 140$ & $10 \sim 70$ & $60 \sim 160$ & $25 \sim 110$ & $0 \sim 30$ & $0 \sim 128$ \\
\hline
\end{tabular}




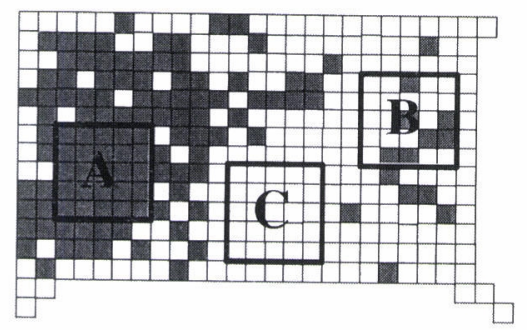

抽出画素の割合 $\left(R_{p v}\right)$
$\mathrm{A}: 100 \%$
$\mathrm{~B}: 24 \%$
$\mathrm{C}: 0 \%$

※着色部は，抽出された画素を表す

図12 局所領域における抽出画素の割合 $\left(\boldsymbol{R}_{p x}\right)$ の考え方

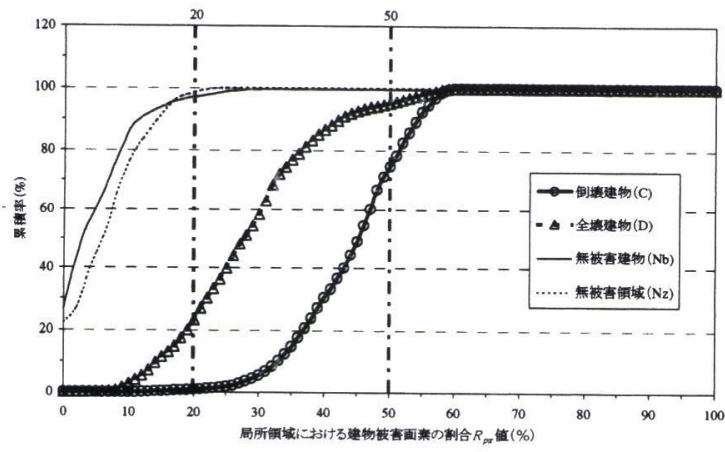

図13 $\boldsymbol{R}_{p x}$ の平均相対頻度の累積分布

は建物 1 棟と同程度の大きさとし, 画像の上部と下部 では地上分解能が異なることから, 上部で $31 \times 31$ 画素, 下部で $63 \times 63$ 画素になるように線形的に変化させた。 図13にトレーニングデータに打ける $R_{p x}$ 值の相対頻 度の累積分布を示す。なお，それぞれの項目の平均值 を示している。 $R_{p x}$ 值が20\%以下では, 無被害地域 $(\mathrm{Nb}, \mathrm{Nz})$ の画素の $95 \%$ 以上がその範囲に含まれるが, 倒壊建物 (C) では $1 \%$ も満たない。一方， $R_{p x}$ 值が $50 \%$ 以上の画素はそのほとんどが倒壊建物に存在する。

被害画素に対してフィル夕解析を行った結果を表 1 の(7)に示す。 $R_{p x}$ 值 $20 \%$ 以下を濃灰色, $R_{p x}$ 值 $50 \%$ 以上 を白色として，その中間は值が高くなるにつれ白色に 変化させている。最終的に抽出された画素の抽出率は, 倒壊建物（C）で $99.1 \%$ ，全壊建物（D）で76.7\%，無 被害建物 (Nb) で2.9\%, 無被害領域 $(\mathrm{Nz})$ で1.5\%で ある。建物被害 (C, D) の画素抽出率は非常に高く, 倒壊建物 (C) はほぼすべてが被害画素として抽出され ており，全壊建物(D) についても被害を受けた筒所が 多く抽出されている。一方無被害建物 $(\mathrm{Nb})$ 拈よび無 被害領域 $(\mathrm{NZ})$ の画素抽出率は非常に低い。トレーニ ングデー夕に対する本手法の被害抽出は, 詳細な被害 判読は行之ないものの, 大被害建物にみられる特徵的 な被害を高い精度で抽出している。

この抽出手法を対象地域全域に適用した結果を図14 $-34-$

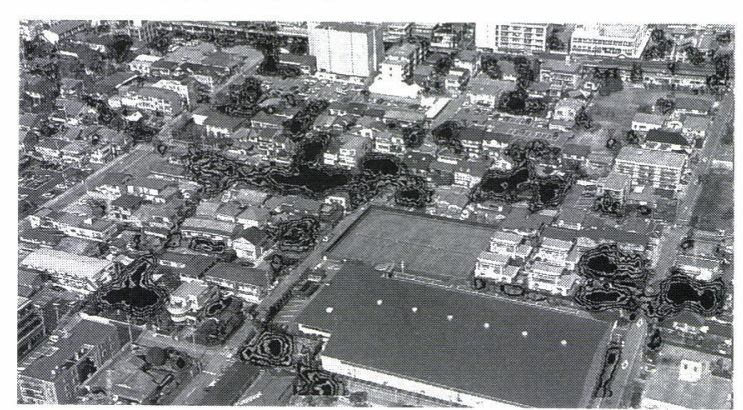

(a) 画像処理により抽出された被害建物（ $\boldsymbol{R}_{p x}$ 值20\%以上 をコンター表示)

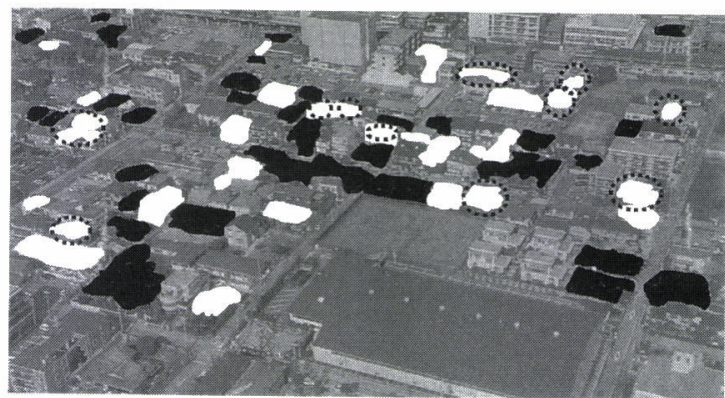

(b) 地上調査データおよび目視判読に基づく全壊, 倒壊建 物の分布 (白: 全壊建物, 黒 : 倒壊建物, 点線: ブルー シートの建物)

図14 対象地域における被害建物の抽出結果および実際の 被害分布

(a)に示す。また，図14(b)には被害建物の地上調查デ一 夕6),7)及び目視被害判読2)に基づく倒壊および全壊建物 の分布を示す。ほぼすべての倒壊建物と, 全壊建物の 一部が, 本手法により抽出できている。また, その抽 出結果から, 1 棟単位の倒壊建物や建物被害箇所を概 ね同定できている。抽出されなかった全壊建物の多く はブルーシートの建物である。さらに, 先の対象地域 と異なる 2 つの地域 (地域 B，C) を撮影した画像に対 して抽出手法を適用した結果とブルーシートの建物を 対象外とした実際の被害分布を図15，16に示す。非木 造建物の空付近などに若干の誤判別がみられるもの の, 倒壊建物のほとんどが抽出できている。従って, 


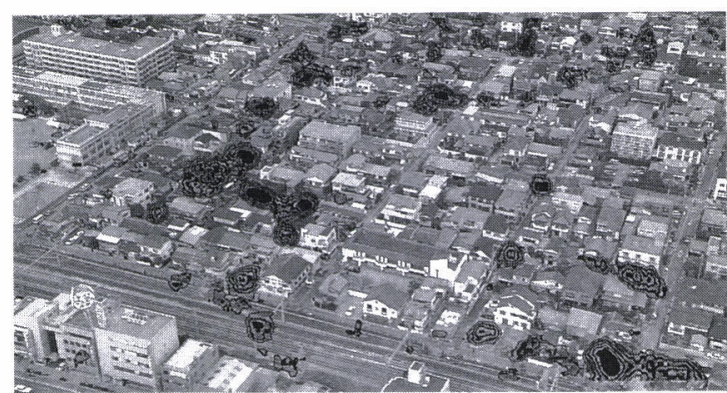

(a) 画像処理により抽出された被害建物（ $\boldsymbol{R}_{p x}$ 值20\%以上 をコンター表示)

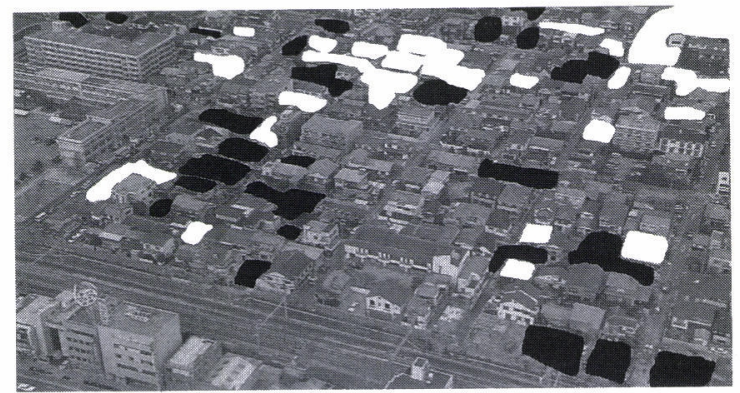

(b) 地上調査データおよび目視判読に基づく全壊, 倒壊建 物の分布（白：全壊建物, 黒：倒壊建物）

ブルーシートの建物は対象外

図15地域 Bにおける被害建物の抽出結果および実際の被 害分布

対象範囲を拡大して, トレーニングデータのない地域 に本手法を適用した場合でも甚大な被害を受けた建物 の分布を迅速に抽出できる。

サイドルッキングで撮影された画像では建物側面の 情報が得られ，これが被害の抽出をし易くしている可 能性がある。そこで, 直下を撮影した航空写真につい て本手法を適用し, 観測条件が被害抽出に及ぼす影響 について検討した。使用した航空写真は, 地震発生後 2 日目（1995年 1 月18日）に撮影された縮尺 $1 / 4,000$ の垂直写真の一部である。対象地域は, 八イビジョン 画像と同じであるが, 地震発生直後に撮影されている ことからブルーシートはみられない10)。

ここでは, アナログ情報である航空写真を, スキャ ナを用いてビットマップ形式の画像ファイル $(880 \times$ 1068画素) に変換して使用した。画像の地上分解能は 約 $23 \mathrm{~cm}$ である。画像内で地上分解能にほとんど違い がないことから, 自動抽出にあたり, $R_{p x}$ 值を求める局 所領域を $31 \times 31$ 画素の固定としている。罒17に, 被害 の自動抽出および実際の被害分布を示す。ハイビジョ ン画像の検討に用いたトレーニングデータに対応する

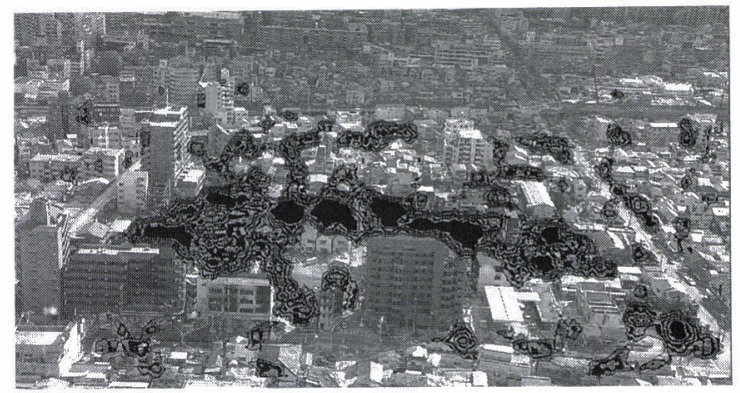

(a) 画像処理により抽出された被害建物（ $\boldsymbol{R}_{p x}$ 值20\%以上 をコンター表示)

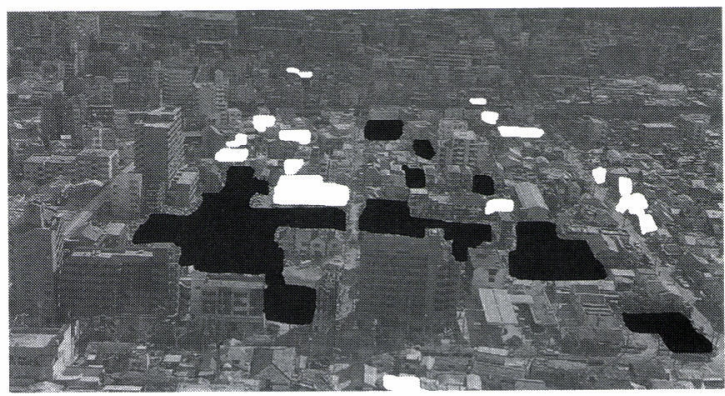

(b) 地上調査データおよび目視判読に基づく全壊, 倒壊建 物の分布（白：全壊建物, 黒：倒壊建物）

ブルーシートの建物は対象外

図16地域 Cにおける被害建物の抽出結果および実際の被 害分布

領域について, 被害画素の抽出率を求めてみると, 倒 壊建物（C）で98.9\%，全壊建物（D）で67.4\%，無被 害建物 $(\mathrm{Nb})$ で6.2\%, 無被害領域 $(\mathrm{Nz})$ で0\%であ る。直下視であっても倒壊建物 $(\mathrm{C})$ の抽出精度は高く, 八イビジョン画像の抽出結果と同程度の結果が得られ ている。

\section{6. まとめ}

1995年兵庫県南部地震後に撮影された空撮ハイビ ジョン画像を用いて, 画像情報から被害建物と無被害 建物を判別するための指標やその組み合わせを検討 し, 色相, 彩度, 明度の各中間值, エッジ強度, エッ ジ強度の分散およびエッジ方向の最頻度が両者を判別 する指標として有効であることを確認した。そして， それぞれの指標に設定した閾值から被害に対応する画 素を選定し，その空間的な割合から被害地域を抽出す る手法を提案した。この手法を空撮画像に適用したと ころ, 大被害にみられる特徴的な建物被害を高い精度 で抽出できることを示した。また抽出結果より，木造 


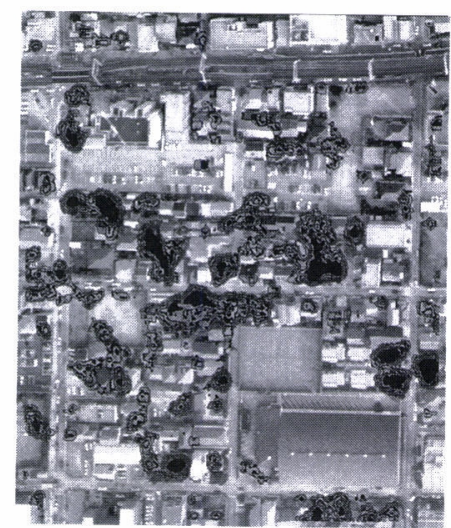

(a) 画像処理により抽出された被害建 物 ( $\boldsymbol{R}_{p x}$ 值 $20 \%$ 以上をコンター表示)

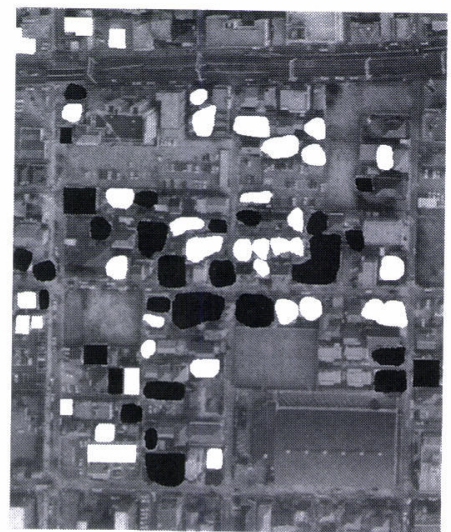

(b) 地上調査データおよび目視判読に 基づく全壊, 倒壊建物の分布 (白：全 壊建物，黒：倒壊建物)

\section{図17航空写真における建物被害の抽出結果および実際の 被害分布}

の倒壊建物と全壊建物の被害箇所を概ね判読可能であ ることを示した。ただし，本報で提案する被害抽出手 法は判別指標の閾値の僅かな変化によりその結果は変 わり，また，画像解析に先立ち実施する濃度変換法の 違いによっても抽出結果は異なる。そのため，手法を 一般化するためには検討事例を蓄積し，手法や指標こ れらの閾值を最適化する必要がある。最後に，本報は 対象建物を木造に限定していた。今後は，建物側面部 の情報を有効に活用し，非木造建物も対象に含めた被 害抽出手法の構築を目指していく予定である。
謝辞

本研究は侏建設企画コンサルタントの長谷川弘忠, アジア航測(侏)の小川直樹の両氏が理化学研究所に在職 中に実施した研究を発展させたもので，両氏からの多 大なる助言を得ている。また,ここで用いた八イビジョ ンデータは NHK との共同研究により提供して頂い た。記して謝意を表する。

(受付日2001.2.19, 受理日2001.7.6)

\section{参考文献}

1）建設省：災害情報システムの開発報告書 災害情 報システム・ガイドライン(案)，1992.

2 ）長谷川弘忠，山崎文雄，松岡昌志，関本泉：空撮 八イビジョン映像を用いた兵庫県南部地震の建物被 害把握の試み, 第 3 回都市直下地震災害総合シンポ ジウム論文集，pp.427-430，1998.

3 ）長谷川弘忠, 山崎文雄, 松岡昌志：空撮ハイビジョ ン映像を用いた兵庫県南部地震による建物被害の目 視判読, 土木学会論文集, No. 682/I-56, pp.257-265, 2001.

4 ）青木久, 長谷川弘忠, 山崎文雄, 関本泉：空撮映 像を用いた地震被害建物分布の自動抽出, 日本リ モートセンシング学会第28回学術講演会論文集, pp. 89-92, 2000.

5 ）松岡昌志，山崎文雄，翠川三郎：1995年兵庫県南 部地震での被害地域における人工衛星光学セン州画 像の特徵, 土木学会論文集, No.668/I-54, pp.177185, 2001 .

6 ）震災復興都市づくり特別委員会：阪神・淡路大震 災被害実体緊急調査 被災度別建物分布状況図集 (説明書)，1995.

7 ）建設省建築研究所：「阪神・淡路大震災復興計画策 定支援システム」に係る数值化データ，1996.

8 ）高木幹雄, 下田陽久：画像解析ハンドブック, 東 海大学出版会, 1991.

9) 日本リモートセンシング研究会：新編リモートセ ンシング用語辞典，共立出版，1996.

10）小川直樹, 山崎文雄：航空写真を用いた兵庫県南 部地震における建物被害の目視判断, 地域安全学会 論文集，No. 2, pp.119-128， 2000. 